\title{
A CASE STUDY ON GERUGU DAM OVERTOPPING UNDER DIFFERENT PMP SCENARIOS
}

\author{
Heng Hock Hwee ${ }^{1}$ and Hii Ching Poon ${ }^{2}$
}

\begin{abstract}
A hydrological dam safety inspection was carried out for existing Gerugu dam $\left(\mathrm{CA}=14 \mathbf{k m}^{2}\right)$ by evaluating the hydrological performance of the bellmouth spillway in light of two different sets of Probable Maximum Precipitation (PMP). For safety reason, it is utmost important that the flood rise does not exceed the embankment dam crest level (ECL). Gerugu dam (CA=14 $\mathbf{k m}^{2}$ ) is a small catchment earthfill zoned embankment dam that supplies raw waters to the water treatment plant downstream. This study selects both "coastal" type of PMP [13], [14] which is mostly representative of the extreme precipitation parameters adopted in the design of the dam and a recent set of PMP under NAHRIM [11] study. A catchment routing procedure is then used to translate the PMPs to PMFs for 1- to 120-hour duration and a conventional reservoir routing in tandem to estimate the outflows and corresponding flood rise over the full supply level (FSL) of the reservoir. The dam is considered safe under both coastal and NAHRIM [11] PMP scenarios as the flood rises for all cases are confined below the embankment crest level (ECL), i.e. $+33.0 \mathrm{~m}$ msl.
\end{abstract}

Keywords: Dam Overtopping, Coastal PMP, NAHRIM PMP, PMF,

\section{INTRODUCTION}

$\mathrm{D}$

AMS have served many beneficial purposes in the water resources system and management. They are constructed to moderate the fluctuating inflows that vary in both spatial and time domain. For example, low flow at the downstream of a water supply dam is being augmented by the releases during drought season. This is an important aspect of a water supply reservoir operation scheme to be able supply adequate raw water timely to make up the deficit in the natural river source.

Another important function of the reservoirs is its surcharging capacity to attenuate high inflows during storm events. This is accomplished by ample storage above dams' full supply level during an impending extreme weather event. Normally, dams/reservoirs are built to withstand hosts of anticipated design physical forces. Stresses are caused or developed by (1) earthquakes, (2) extreme meteorological situations, such as an extraordinary torrential rain storms that pouring into the reservoir, and (3) development of risk of internal piping due to uncontrolled seepage inside the dam body and structure, and many others.

Failures of dam structure by overtopping highlight the need of accurate assessment of their safety feature such as emergency action can be planned and implemented ahead of probable catastrophic events [5], [10], [18]. One of these measures is the hydrological inspection and evaluation that plays a role in the overall inspection program to estimate the overtopping probability of the dam/reservoir in light of an extreme meteorological event, i.e. during a probable maximum precipitation (PMP) scenario.

Amongst the dam structural appurtenances, spillway capacity is one of the most significant factors attributed to the ability of a dam to pass the maximum flood. This maximum flood magnitude is estimated based on the probable occurrence of a extreme storms, i.e. Probable Maximum Flood (as derived from PMPs). In other words, the dam body itself is designed such that risk of overtopping will be minimum by adopting the highest design storm and flow, which is also known as spillway design flood (SDF).

In particular, earth and rock fill type of embankment dams are the most vulnerable to failure by overtopping. If the dam is being overtopping by the uncontrolled overspill, a high velocity flow field both at the crest and downstream face of the dam body is to be expected. This high velocity in turns induces cavitation at the location of negative pressure zone. As a result, this would cause erosion of the downstream face of the dam structure. On the other hand, concrete gravity and rolled compacted concrete dams are less susceptible as they are constructed of higher strength materials compared to the compacted earth and rock structures.

\footnotetext{
${ }^{1}$ Heng Hock Hwee is an independent hydrological engineer. (e-mail: henghhwee@ gmail.com)
}

${ }^{2}$ Hii Ching Poon is an independent researcher. (e-mail: Hiicp6588@ yahoo.com) 
The other equally menacing failure is piping or internal erosion due to excessive seepage of water through the earth and rockfill dam structure itself. In general, mechanisms of overtopping and piping failure remain lacking and mostly unknown. For practical purpose, the dam is designed to withstand the onslaught of the most severe meteorological extremities that could happen in its life time. In this regard, PMP/PMF convention is chosen as such with the objectives to investigate the risk of overtopping of the existing Gerugu dam $\left(\mathrm{CA}=14 \mathrm{~km}^{2}\right)$ in the upper catchment of Sarikei River, the assessment is carried out under two different PMP scenarios; compare the relationship of catchment area-weir length-headrise relationships with existing dam/reservoir schemes in the same meteorological/hydrological region; and recommend, if any, the remedial measure(s)/option(s) to mitigate the deficiency in spillway capacity.

\section{DESCRIPTION OF STUDY}

Gerugu damsite is located on Gerugu river, a tributary of Sarikei river at about $450 \mathrm{~m}$ upstream of the confluence of the two streams. It originates from $7.4 \mathrm{~km}$ South-West of the dam site, at an elevation of $110 \mathrm{~m} \mathrm{msl}$, draining an area of $13.6 \mathrm{~km}^{2}$. The river traverses a length of about $13.6 \mathrm{~km}$ up to the dam site where the river bed elevation is at level $2.0 \mathrm{~m}$ LSD. The catchment area comprises of hilly and undulating topography with fairly steep gradients in the upper reaches. The entire catchment is covered by forests, some medium size rubber plantation or estate and small scale slash and burn type of sporadic cultivation. Gerugu dam $\left(C A=14 \mathrm{~km}^{2}\right)$ was built in the mid 1990's as part of a long-term integrated water supply scheme for the town of Sarikei and its vicinity. The dam operates as a regulating reservoir mode by releasing waters to the treatment plant immediately downstream in case of shortfall from the pumping station. The dam is a 33-m high earthfill embankment dam with a crest length of $200 \mathrm{~m}$. The locality of the Gerugu dam can be found in Figure 1 shown below.

The impounded reservoir stores up to $14 \mathrm{MCM}$ at its full supply level (FSL), i.e. $+30.0 \mathrm{~m}$ msl though only slightly less than 10 MCM is required to mitigate through the 1:50-year design drought. The embankment crest level (ECL) is at $+33.0 \mathrm{~m} \mathrm{msl}$. This effectively gives some $3.0 \mathrm{~m}$ of headroom for flood attenuation during extreme flooding events. The lake surface area is smaller due to steeper lake configuration, only commands about $1.2 \mathrm{~km}^{2}$ at FSL level. This is also indicative of the steeper catchment topography upstream of the dam site.

The dam is equipped with a variable level intake tower and a morning glory or drop shaft type of spillway. Similar to other type of water supply dam, it is commonly operated up the FSL level for full and efficient utilization of its storage volume. The effective diameter of the morning glory spillway is $10.0 \mathrm{~m}$. Based on Vischer and Hager [19] recommendation, the upper limit of the hydraulic head shall be about $2.0 \mathrm{~m}$ above the FSL if an upper ratio of head over radius of 0.40 is adopted. The significance of this ratio is to effectively allow open surface weir flow mode of hydraulic condition at the spillway if the hydraulic head is less than this threshold value. Increasing the hydraulic head over spillway weir will change the mode from weir flow to orifice and conduit flow modes and may risk cavitation damage in the tunnel shaft.

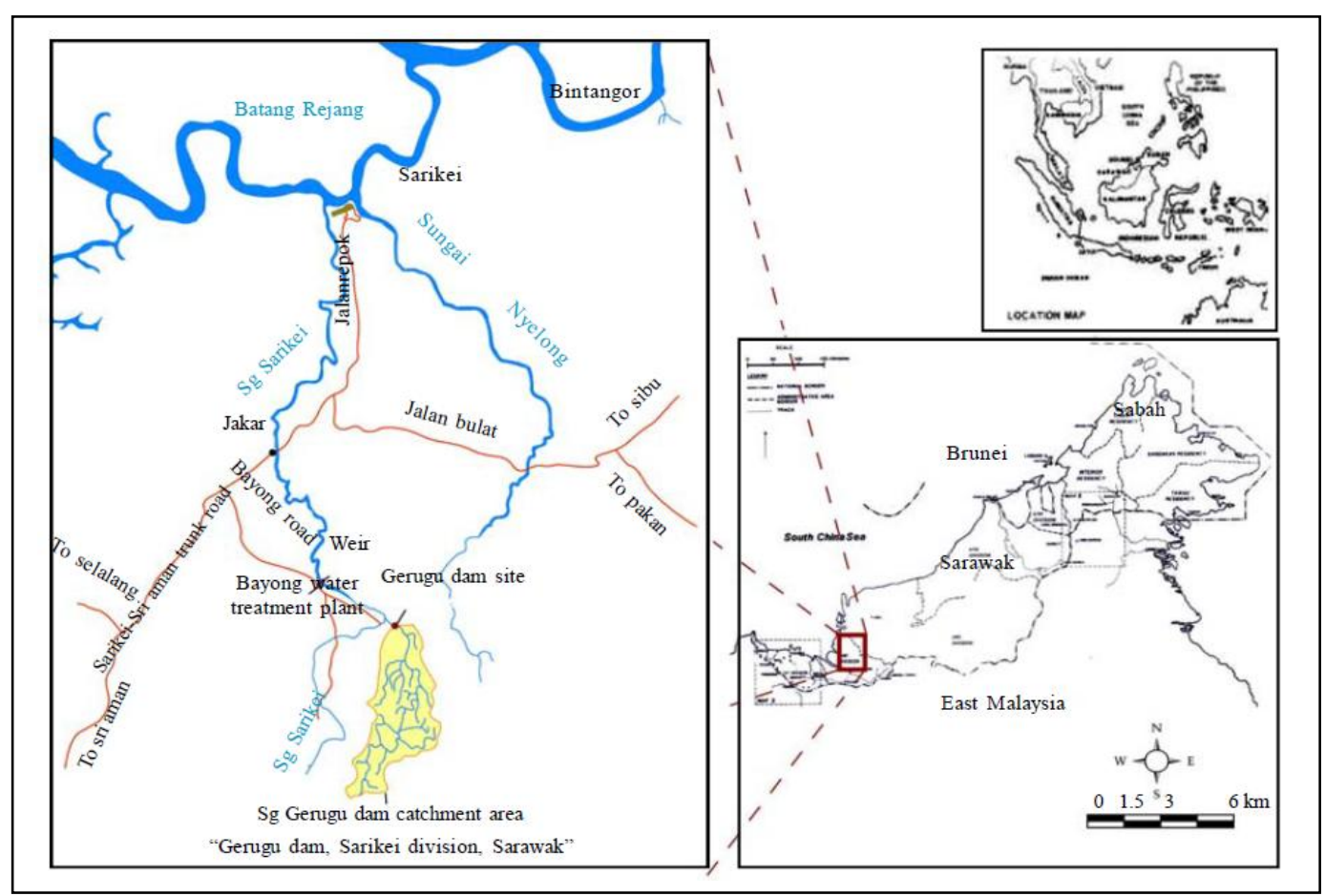

Figure 1 - Locality of Gerugu Dam in the Upper Catchment of Sarikei River basin. 


\section{METHODOLOGY}

The methodology of assessing the hydrological dam safety, primarily envisages the review of the spillway capacity and dam overtopping likelihood. The steps involved are (1) derivation of PMPs at the project/study site, (2) translation of PMPs to PMFs/SDFs using a catchment rainfall runoff or response function model, and (3) a conventional reservoir routing technique to estimate the flood rise over the dam's full supply level (FSL).

The derivation of PMPs is carried out in this study, mostly by reviewing the available past studies and findings in Malaysia. The prevailing PMP convention is duly reviewed and adopted as appropriate. Catchment response and convolution lumped parameter model is used to translate PMPs to PMFs for various durations. Finally, the derived PMFs are then appropriately routed through a lumped parameter reservoir. The final results of this exercise/undertaking are to ensure the dam is not overtopped passed its embankment crest level (ECL).

Probable Maximum Precipitation (PMP) represents the upper limit of the precipitation/rainfall under probable and favorable contributing factors, such as availability of moisture and other favorable meteorological conditions, absence/presence of moisture barrier such as higher mountainous range in the path of storm movement, availability of cumulus or particle that water vapors can be adhered to and others.

Probable Maximum Precipitation (PMP) is derived based on mostly observed maximum rainfall records with the provision of storm maximization and transposition technique in tandem [21]. Based mostly on practical experiences in Malaysia, PMPs are derived based on the historical maximum rainfall records mostly in the east coastal regions of the Peninsular Malaysia. This region is exposed to more severe storm event during monsoon season.

The observed records that were collected over the years, both recording and non-recording maximum rainfalls alike. These records provide the basis of PMP derivation. Major undertakings were carried out in the Kelantan Flood Mitigation Project [16], National Water Resources Study [15] and Interstate Raw Water Transfer from Pahang to Selangor [12]. A review of past PMP studies can also be found in Desa et al [6], Al-Maimum and Hashin [1], Desa and Rakhecha [7], NAHRIM [11] and Heng and Hii [9].

In this study, for uniformity, PMPs derived by SMHB [13], [14] and recent NAHRIM [11] are adopted. For the former, two series of PMPs based on the geographical location of the proposed dam site, namely (1) coastal and (2) inland PMP series were used in most of the dam design projects in Malaysia. The coastal series was derived earlier in the late 1970's based on observed records of long-duration storm occurrences in the eastern coastal region of the peninsular Malaysia. The observed records of Mersing and Air Tawar were used. The highest rainfall records in the 1970's are not in any way exceeded with the recent studies by Atikah [2] and NAHRIM [11]. On the other hand, the inland series is merely a reduced version of the coastal PMP with a transposition factor to the inland region/site of the western coast of Peninsular Malaysia.

In general, coastal PMP represents the most severe storms on the east coastal sea front, due to unavailability of the PMP information on Gerugu dam $\left(\mathrm{CA}=14 \mathrm{~km}^{2}\right)$, it is assumed that the coastal PMP is equally applicable to other side of the South China Sea.

Recent NAHRIM [11] study presents the PMPs for 0.5-hour to 168-hour duration using both statistical and rigorous hydrometeorological approaches. Both approaches give entirely different order of magnitude of PMPs. Generally these recent NAHRIM [11] PMPs are slightly higher than both the coastal and inland PMPs. The only closest point rainfall stations to the dam site are at Nanga Jagau and Song rainfall station, in the neighboring catchments. To exercise conservatism in PMP estimate, Rainfall station at Song is adopted to represent the PMP episodic event at the dam site. Table 1 summarizes the PMPs for both coastal and inland regions and NAHRIM [11].

Table 1: Coastal, Inland, and NAHRIM [11] PMP (Short- and Long-Duration)

\begin{tabular}{|l|r|r|r|r|}
\hline Duration (hour) & $\begin{array}{r}\text { Coastal } \\
\text { PMP }(\mathrm{mm})\end{array}$ & $\begin{array}{r}\text { Inland PMP } \\
(\mathrm{mm})\end{array}$ & $\begin{array}{r}\text { Jagau PMP } \\
(\mathrm{mm})\end{array}$ & $\begin{array}{r}\text { Song } \\
\text { PMP (mm) }\end{array}$ \\
\hline 1-hour & 211 & 188 & 288 & 295 \\
\hline 3- hour & 338 & 300 & 479 & 490 \\
\hline 6- hour & 440 & 391 & 576 & 589 \\
\hline 12- hour & 584 & 518 & 639 & 660 \\
\hline 24- hour & 777 & 692 & 750 & 774 \\
\hline 48- hour & 1356 & 908 & 936 & 964 \\
\hline 72- hour & 1593 & 1067 & 1488 & 1538 \\
\hline 120- hour & 2030 & 1360 & 1577 & 1630 \\
\hline
\end{tabular}

Adopted by NAHRIM [11;] SMHB [13], [14]

Translating and routing by convolution of temporally distributed PMPs into PMFs of various rainstorm durations, i.e. from 1- to 120-hour is one of the important tasks in a standard PMP/PMF study. Out of many hydrological rainfall runoff techniques available, two (2) approaches or models are the most commonly used in the local context, (1) hydrological procedure No: 11 on flood estimation [17], and (2) modeling approach using proprietary as well as nonproprietary mathematical models/software. For uniformity as well as simplicity, the former is adopted in this study.

The outlet structures, such as sluice gates at the bottom outlet and spillways of a dam shall be able to evacuate an extreme flood of PMP/PMF magnitude for the protection of the main dam body. Overtopping due to inadequacy of the outlet and/or spillway capacity is accountable for most of the dam failure worldwide [22].

Water balance description can be quantitative written in the form of flow continuity equation over a fixed domain, in this case, in a reservoir. The rate of change of storage in the reservoir water body is the summation and quantification of all inflows from 
various sources and appropriately deducting the amount of outflow via outlet structures, such as spillways or bottom outlet of a reservoir/dam. For simplicity, it is assumed that other losses such as seepage through the dam body are negligible.

\section{RESULTS AND DISCUSSIONS}

The results of this study are presented in two (2) parts, namely, on the derivation of PMP/PMF using an acceptable catchment routing procedure based on Snyder synthetic hydrograph concept and on the results of reservoir routing and estimation of flood rise using a modified approach attributed to Puls [4].

The catchment routing adopted in this study is one of the simplest procedures based on Snyder type of synthetic unit hydrograph approach. Firstly, the estimated $10 \mathrm{~mm}$ unit hydrograph is derived for Gerugu dam catchment $\left(\mathrm{CA}=14 \mathrm{~km}{ }^{2}\right)$. The PMP/PMF hydrographs of two different scenarios are shown in Figure 2.
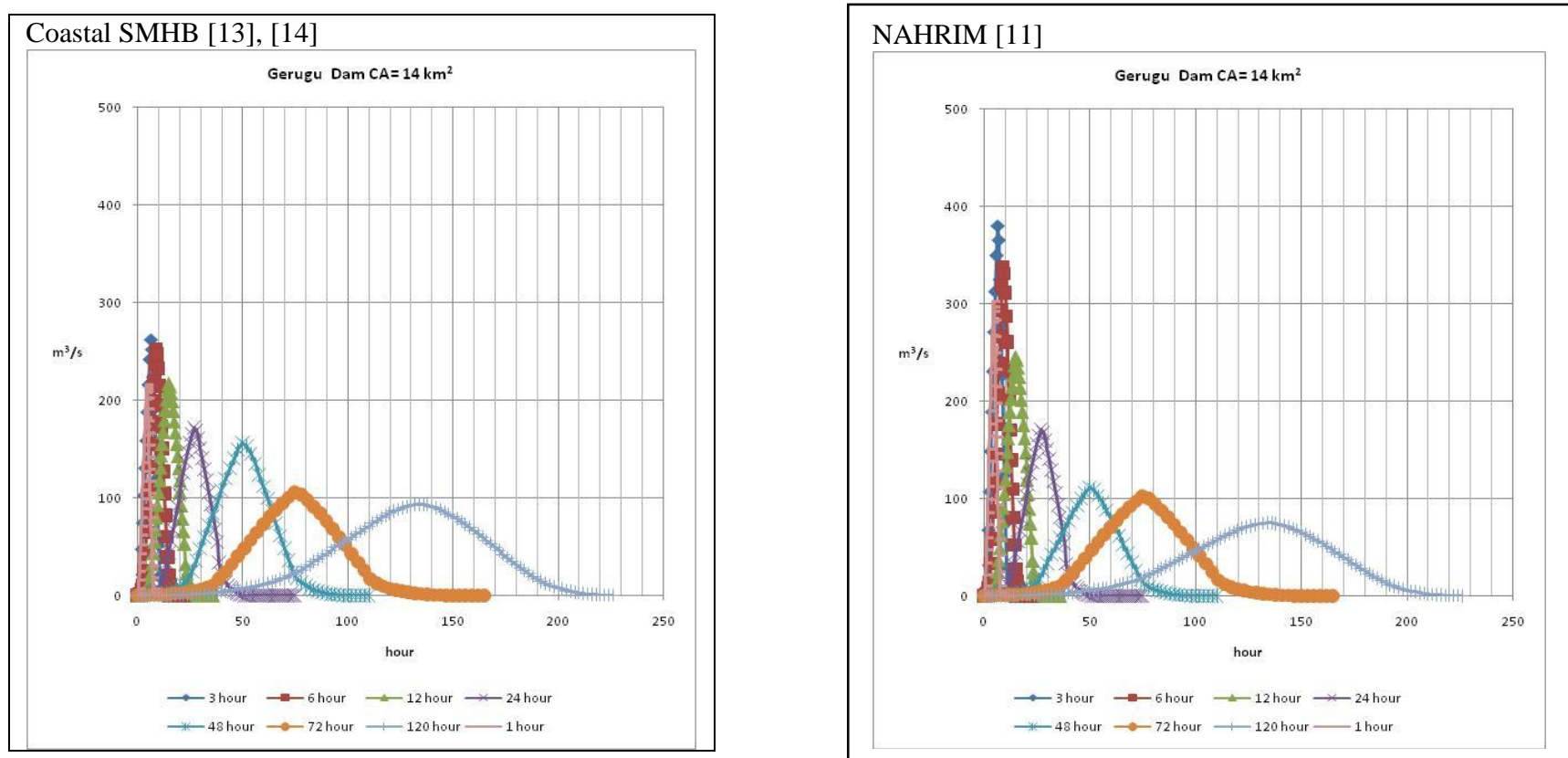

Figure 2 - Various PMP/PMF Hydrographs Derived for Coastal SMHB and NAHRIM Scenarios

The primary purpose of a reservoir routing is to determine the outflows and corresponding flood rises of the PMPs/PMPs as they pass through the reservoir. It is desirable that the maximum flood rise for various durations, i.e. from 1 - to 120 -hour is less than the embankment crest level (ECL) of Gerugu dam, i.e. $+33.0 \mathrm{~m} \mathrm{msl}$, failing which, would run into the risk of being overtopped.

The reservoir routing results show the flood rises for all durations under both coastal [13], [14] and NAHRIM [11] PMP scenarios are basically confined to below the ECL level. Therefore the dam is deemed safe from overtopping. The highest outflows for both scenarios are during the 6-hour duration, i.e. 177 and $242 \mathrm{~m}^{3} / \mathrm{s}$ respectively. The corresponding flood rises for the most severe case, i.e. coastal PM is $+32.40 \mathrm{~m} \mathrm{msl}$. This essentially gives about $0.60 \mathrm{~m}$ for freeboard and wave run-up that might occur in conjunction with the PMP/PMF event.

The water depth over the radius of the spillway for an open weir flow mode is about 0.35 to 0.50 [19]. With a diameter of 10.0 $\mathrm{m}$ of the spillway, and if assuming a depth-radius ratio of 0.50 is applicable, the maximum allowable headrise before the flow regime changes from weir to orifice and conduit flow is estimated at about $2.5 \mathrm{~m}$ over the FSL. This corresponds to some 260 $\mathrm{m}^{3} / \mathrm{s}$ of spillway capacity. Beyond this range, a sharp rise with lower flow over the weir of the bellmouth spillway is evident in the flow-discharge relationship. Gerugu dam $\left(\mathrm{CA}=14 \mathrm{~km}^{2}\right)$ is considered under both PMP scenarios. The results of this study are consistent with the design spillway capacity of about $250 \mathrm{~m}^{3} / \mathrm{s}[10]$.

Table 2 shows the summary of the results of outflows and their corresponding flood rises. Figure 3a and 3b show the results of PMP/PMF inflow and outflow routing hydrographs.

Table 2: Results of PMP/PMF Reservoir Routing: 1- to 120-hour Duration

\begin{tabular}{|c|c|c|c|c|c|c|c|}
\hline $\begin{array}{c}\text { Duration } \\
\text { Hour }\end{array}$ & Unit hydrograph Q & $\begin{array}{l}\text { Time to } \\
\text { peak tp }\end{array}$ & $\begin{array}{c}\text { Base Flow } \\
\text { Time tb }\end{array}$ & PMP & PMF & $\mathrm{Q}$ & Flood rise \\
\hline & $\mathrm{m}^{3} / \mathrm{s} / \mathrm{cm}$ & hour & hour & $\mathrm{mm}$ & $\mathrm{m}^{3} / \mathrm{s}$ & $\mathrm{m}^{3} / \mathrm{s}$ & $\mathrm{m} \mathrm{msl}$ \\
\hline \multicolumn{8}{|c|}{ Inland PMP $(1992,1994)$} \\
\hline 1 & 10.55 & 4 & 7 & 211 & 216 & 109 & 31.41 \\
\hline
\end{tabular}


UNIMAS e-Journal of Civil Engineering, Vol. 4: Issue 1/April 2013

\begin{tabular}{|c|c|c|c|c|c|c|c|}
\hline 3 & 8.39 & 5 & 9 & 338 & 262 & 161 & 31.83 \\
\hline 6 & 6.41 & 6 & 12 & 440 & 252 & 177 & 31.95 \\
\hline 12 & 4.36 & 9 & 18 & 584 & 217 & 174 & 31.93 \\
\hline 24 & 2.66 & 15 & 29 & 777 & 172 & 153 & 31.77 \\
\hline 48 & 1.49 & 27 & 52 & 1356 & 156 & 146 & 31.71 \\
\hline 72 & 0.80 & 38 & 74 & 1593 & 105 & 102 & 31.35 \\
\hline 120 & 0.65 & 61 & 120 & 2030 & 93 & 93 & 31.28 \\
\hline \multirow[t]{2}{*}{$\begin{array}{c}\text { Duration } \\
\text { Hour }\end{array}$} & Unit hydrograph Q & $\begin{array}{l}\text { Time to } \\
\text { peak tp }\end{array}$ & $\begin{array}{l}\text { Base Flow } \\
\text { Time tb }\end{array}$ & PMP & PMF & $\mathrm{Q}$ & Flood rise \\
\hline & $\mathrm{m}^{3} / \mathrm{s} / \mathrm{cm}$ & hour & hour & $\mathrm{mm}$ & $\mathrm{m}^{3} / \mathrm{s}$ & $\mathrm{m}^{3} / \mathrm{s}$ & $\mathrm{m} \mathrm{msl}$ \\
\hline \multicolumn{8}{|c|}{ NAHRIM [11] } \\
\hline 1 & 10.55 & 4 & 7 & 295 & 302 & 156 & 31.79 \\
\hline 3 & 8.39 & 5 & 9 & 490 & 380 & 241 & 32.40 \\
\hline 6 & 6.41 & 6 & 12 & 589 & 337 & 242 & 32.40 \\
\hline 12 & 4.36 & 9 & 18 & 660 & 245 & 198 & 32.10 \\
\hline 24 & 2.66 & 15 & 29 & 774 & 171 & 153 & 31.77 \\
\hline 48 & 1.49 & 27 & 52 & 964 & 111 & 106 & 31.40 \\
\hline 72 & 0.80 & 38 & 74 & 1538 & 102 & 99 & 31.32 \\
\hline 120 & 0.65 & 61 & 120 & 1630 & 75 & 74 & 31.10 \\
\hline
\end{tabular}

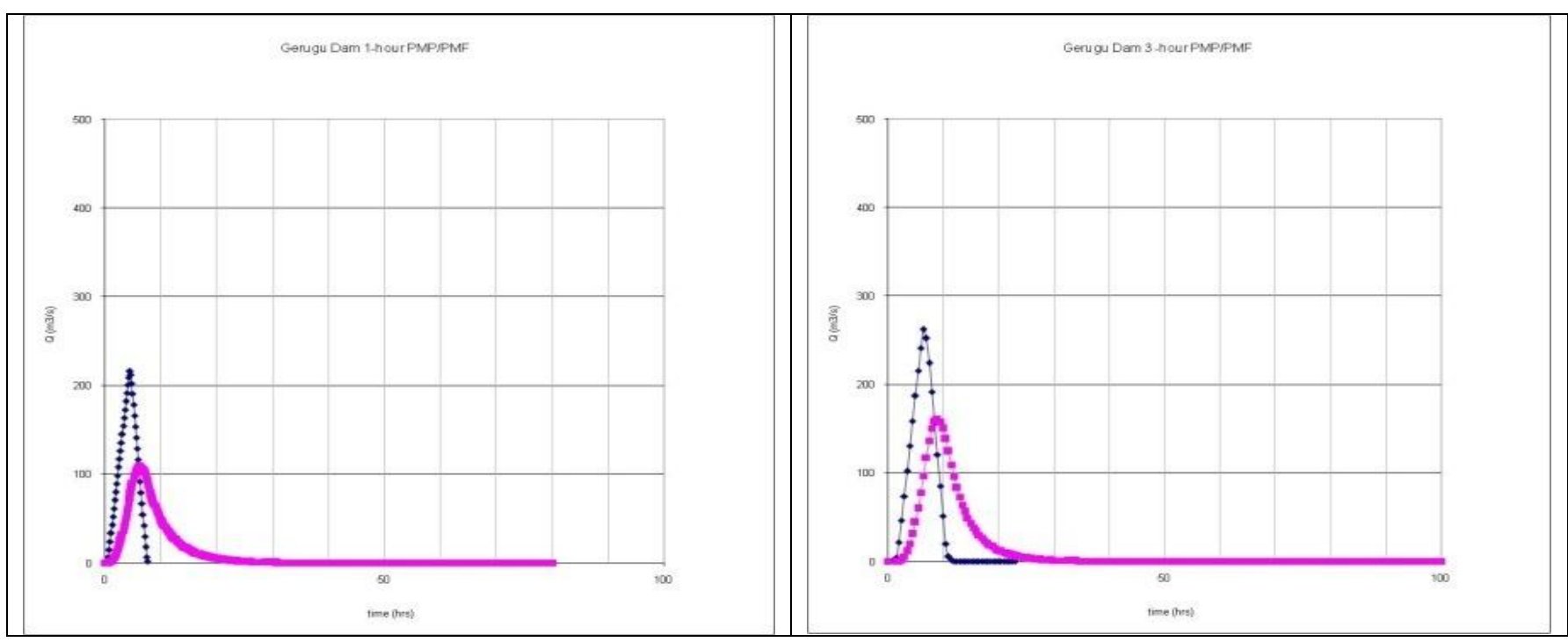


UNIMAS e-Journal of Civil Engineering, Vol. 4: Issue 1/April 2013

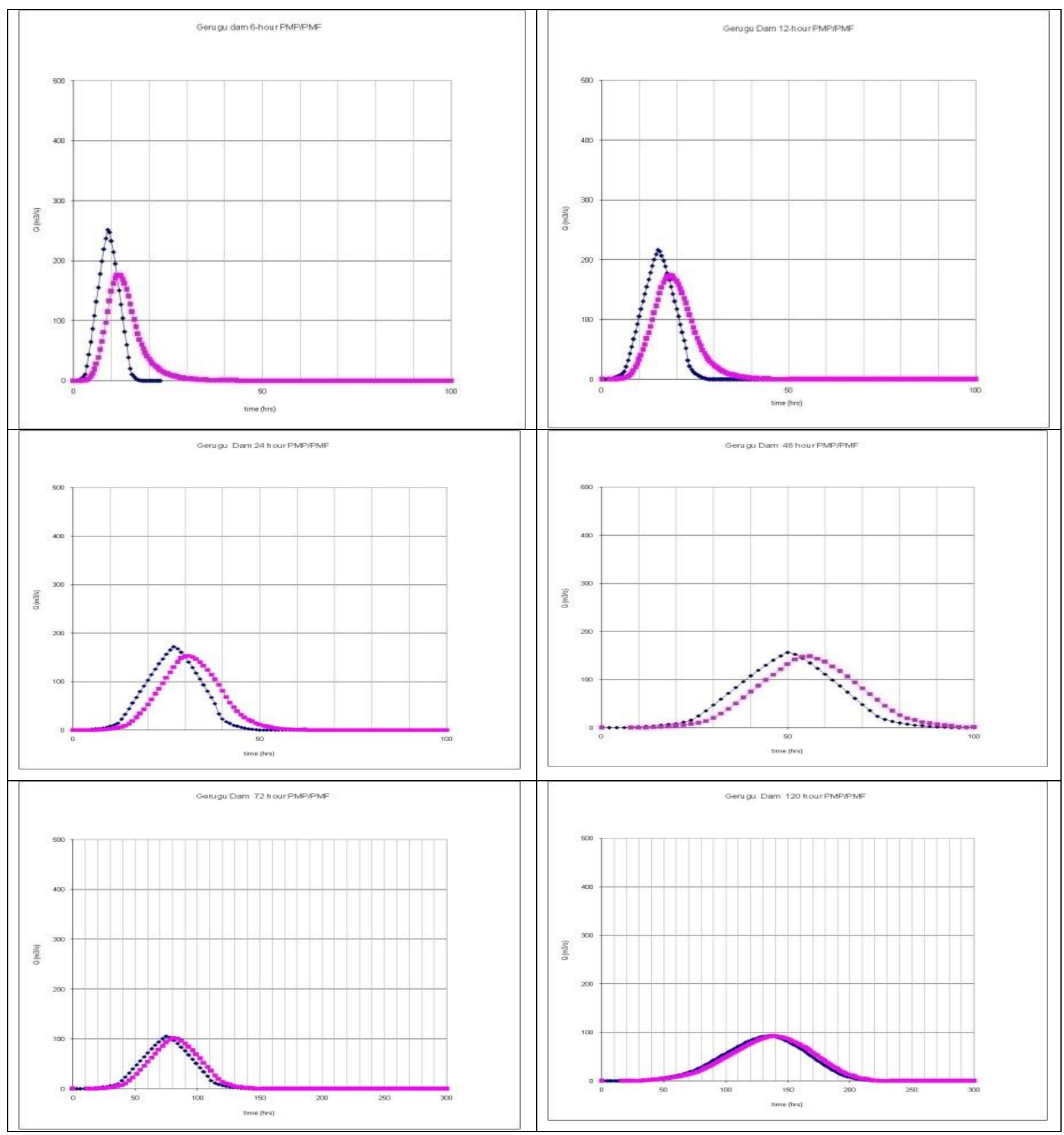

Figure 3a: Gerugu Dam/Reservoir Routing: 1- to 120-hour Duration 1 of 2

SMHB Inland [13], [14] 
UNIMAS e-Journal of Civil Engineering, Vol. 4: Issue 1/April 2013

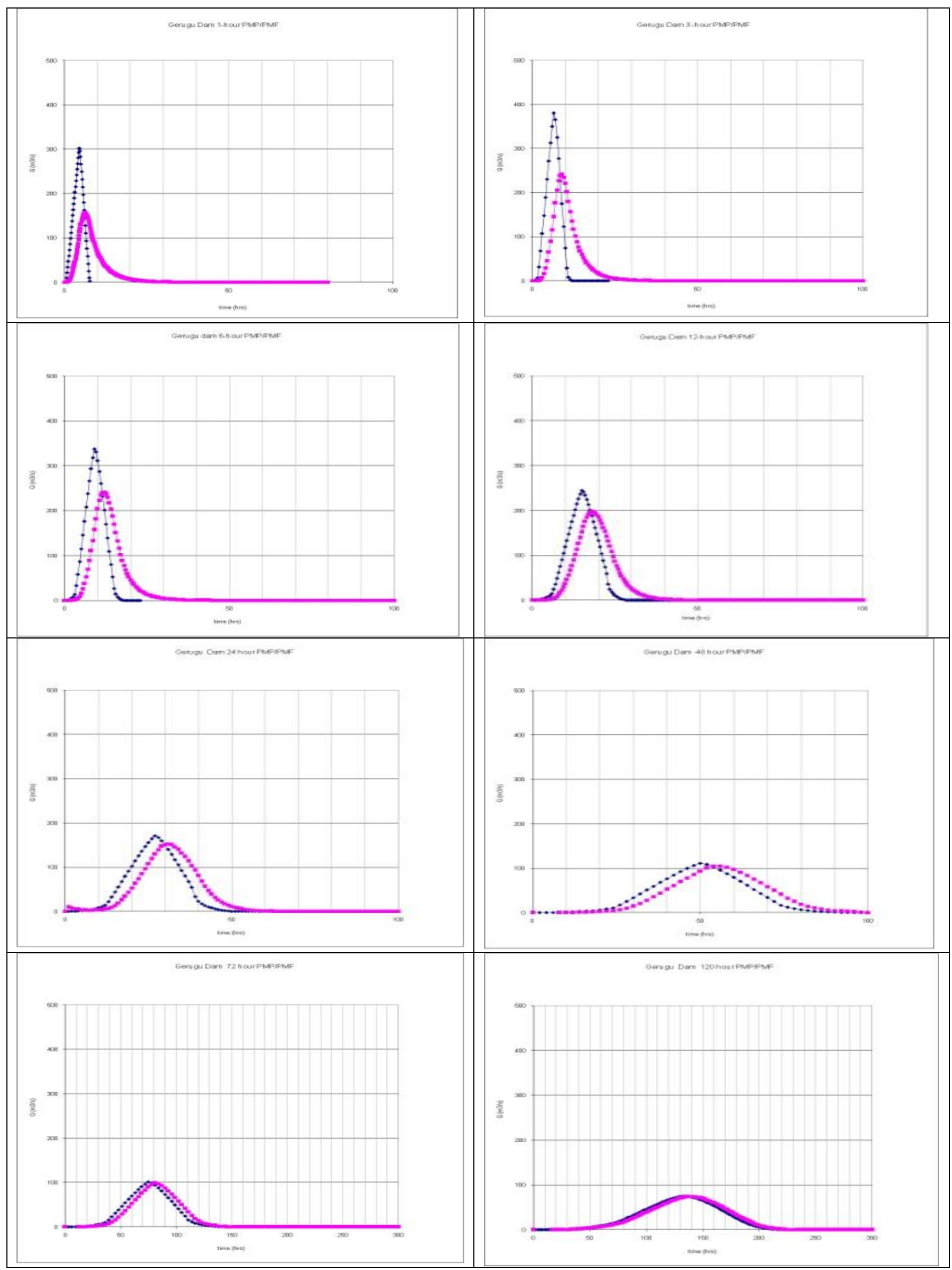

Figure 3b: Terip Dam/Reservoir Routing: 1- to 120-hour Duration 2 of 2 NAHRIM [11]

Morning glory spillway is a common feature for either earth or rockfill embankment dam if suitable sites on the natural ground abutment could not be found. A comparison amongst the existing dams with this type of dropshaft spillway is carried out to 
demonstrate the relationships in terms of their catchment areas, head rises (difference between ECL and FSL) and effective spillway lengths. A summary of dams equipped with bellmouth spillway is presented in Table 3 .

A clear compensating factor is vividly demonstrated by two (2) dams, i.e. Mengkuang $\left(\mathrm{CA}=4 \mathrm{~km}^{2}\right)$ and $\mathrm{Air} \operatorname{Itam}\left(\mathrm{CA}=5 \mathrm{~km}{ }^{2}\right)$, both located in the same meteorological region in the northern peninsular. Though they are of relatively smaller catchment areas but they are equipped with larger bellmouth spillways of longer weir lengths. The headrises for both dams are markedly different even with the about same catchment areas. Air Itam dam with its larger bellmouth spillway can allow a lower flood rise compared to Mengkuang dam with a smaller spillway. Therefore, it can be clearly seen that, a smaller bellmouth diameter such as Mengkuang dam is being compensated by a higher allowable headrise for effective surcharge storage during a PMP/PMF event.

Similar comparison is also made between Tinggi-Semenyih-Langat dams as all of them are located in the same meteorological and topographical regions of Sg. Selangor and Sg. Langat basins. Juasseh dam $\left(\mathrm{CA}=29 \mathrm{~km}^{2}\right)$ and Terip dam $\left(\mathrm{CA}=26 \mathrm{~km}{ }^{2}\right)$ of about the same catchment area but with lower weir length of the former.

With limited information on existing dams with morning glory spillways, it can be demonstrated that both Air Itam $(\mathrm{CA}=5$ $\left.\mathrm{km}^{2}\right)$ and Langat dam $\left(\mathrm{CA}=40 \mathrm{~km}^{2}\right)$ are belong to the same design philosophy where the low headrise is compensating with much larger spillway diameters.

Table 3: Comparison of Catchment Area and Ungated Spillway Width of Selected Dams

\begin{tabular}{|c|c|c|c|c|}
\hline Dam & Catchment area $\left(\mathrm{km}^{2}\right)$ & Spillway width $(\mathrm{m})$ & Headrise/room ECL-FSL (m) & Type of spillway \\
\hline \multicolumn{5}{|c|}{ Northern region } \\
\hline Mengkuang & 4 & 28 & 3.0 & Bell mouth \\
\hline Air Itam & 5 & 69 & 1.3 & Bell mouth \\
\hline \multicolumn{5}{|c|}{ Central region Selangor and Wilayah Persekutuan (Federal Territory) } \\
\hline Tinggi & 40 & 31 & 4.0 & Bell mouth \\
\hline Langat & 41 & 86 & 2.7 & Bell mouth \\
\hline Semenyih & 57 & 44 & 4.0 & Bell mouth \\
\hline \multicolumn{5}{|c|}{ Southern region } \\
\hline Terip & 26 & 61 & 4.0 & Bell mouth \\
\hline Juasseh & 29 & 47 & 4.0 & Bell mouth \\
\hline \multicolumn{5}{|c|}{ Borneo Island } \\
\hline Gerugu & 14 & 41 & 3.0 & Bell mouth \\
\hline
\end{tabular}




\section{CONCLUSION}

A hydrological dam safety exercise was carried out with the objective to assess the performance of the bellmouth spillway of Gerugu dam $\left(\mathrm{CA}=14 \mathrm{~km}^{2}\right)$ in light of an extreme meteorological event of the PMP/PMF magnitude.

This study adopts both "coastal” type of PMPs as derived previously by SMHB [13], [14] and recent review by NAHRIM [11]. A catchment routing procedure is used to translate the PMPs to PMFs for 1-hour to 120-hour duration.

A conventional reservoir routing procedure was then carried out in tandem for all PMP/PMF durations. In general, the flood rises for all durations are lower than the ECL, $+33.0 \mathrm{~m}$ msl under coastal PMP scenario. It is therefore concluded that Gerugu dam $\left(\mathrm{CA}=14 \mathrm{~km}^{2}\right)$ is safe under both scenarios.

\section{REFERENCES}

[1] Al Maimum, A, and A. Hashim. 2004. Generalized Long Duration Probable Maximum Precipitation Isohyetal Map for Peninsular Malaysia. J. Spatial Hydrology, vol. 4(1) pp 212-234.

[2] Atikah, (2009). Extreme Flood Event: A Case Study on Floods of 2006 and 2007 in Johor, Malaysia. Technical Report. Colorado State University, Fort Collins, CO, USA.W.-K. Chen, Linear Networks and Systems (Book style). Belmont, CA: Wadsworth, 1993, pp. 123-135.

[3] Australia Bureau of Meteorology (2003) The Estimation of Probable Maximum Precipitation in Australia: Generalized Short-Duration Method, Bureau of Meteorology, Melbourne, Australia.

[4] Chow, V.T., D.R. Maidment, and L. Mays (1988). Applied Hydrology. McGraw Hill, New York, New York.

[5] Coleman, S.E., D. P. Andews, and M.G. Webby. (2002). Overtopping of Noncohensive Homogeneous Embankment. Journal of Hydraulic Engineering, 128(9), pp 829-830.

[6] Desa MN., A. B. Noriah, P. R. Rakhecha (2001) Probable maximum precipitation for 24 h duration over southeast Asian monsoon region-Selangor, Malaysia. Atmospheric Research, Volume 58, Issue 1, June 2001, Pages 41-54

[7] Desa MN and PR Rakhecha, (2007) Probable maximum precipitation for 24-h duration over an equatorial region: Part 2-Johor, Malaysia. Atmospheric Research Volume 84, Issue 1, Pages 84-90

[8] FEMA (2004). Federal Guideline for Dam Safety: Selecting and Accommodating Inflow Floods for Dams. US Department of Homeland Security, Federal Emergency Management Agency, Washington, DC. USA.

[9] Heng HH \& CP Hii, (2011). A Review on PMP Estimation in Malaysia. Int. Jour. Hydrology Science and Technology. Vol 1 No. 1/2 pp 63-87.

[10] Khoo, F.W.L, Law, P.L., Lai, S.H., Onn, Y.W., and Ting. H.S. (2009). Quantitative Dam Break Analysis on a Reservoir Earth Dam. Int. J. Envron. Sci. Tech., 6(2). 203-210

[11] NAHRIM (2008). Derivation of Probable Maximum Precipitation for Design Floods in Malaysia. Technical research publication (TRP) No. 1, Ministry of Natural Resources and Environment, Kuala Lumpur, Malaysia.

[12] Nippon Koei and SMHB. (2000). Nippon Koei in association with SMHB, 2000. Pahang-Selangor Raw Water Transfer Project Engineering Services and Detailed Engineering Design: Hydrograph, Final Report. Malaysia, JBA, JKR.

[13] SMHB (1992). Study on Comprehensive Water Resources Planning and Development in the State of Pahang. Final report. Economic Planning Unit. Government of Malaysia.

[14] SMHB (1994). Study on Comprehensive Water Resources Planning and Development in the State of Johor. Final report. Economic Planning Unit. Government of Malaysia.

[15] SMHB, Ranhill Bersekutu, and Jurutera Perunding Zaaba (2000). National Water Resources Study 2000-2050. Economic Planning Unit, Government of Malaysia.

[16] SSP and SMHB (1997). Kelantan River Flood Mitigation Project: Feasibility Study. Jabatan Pengairan dan Saliran, Kuala Lumpur, Malaysia.

[17] Taylor, M.A.W and Y.K.Toh (1976). Design Flood Hydrograph Estimation for Rural Catchments in Peninsular Malaysia. Kuala Lumpur, Hydrological Procedure No: 11. (HP 11) Jabatan Pengaliran dan Saliran, Ministry of Agriculture ,Malaysia.

[18] Tingsanchali, T. and S. Tanmanee. (2012). Assessment of Hydrological Safety of Maei Sruai Dam, Thailand. Procedia Engineering, 32, pp 1198-1204.

[19] Vischer, D.L. and W. H. Hager (1998). Dam Hydraulics, Wiley, New York, New York.

[20] WMO (1986). Manual on Estimation of Probable Maximum Precipitation. Operational Hydrology Report No. 332, World Meteorological Organization, Geneva

[21] WMO (2009). Manual on Estimation of Probable Maximum Precipitation. Operational Hydrology Report No. 1045, World Meteorological Organization, Geneva

[22] www.icold.org 
UNIMAS e-Journal of Civil Engineering, Vol. 4: Issue 1/April 2013

\section{LIST OF ABBREVIATIONS}

CA

ECL

FSL

$\mathrm{Km}^{2}$

LSD

MCM

MSL

NAHRIM

PMP

PMF

SDF

Sg.

SMHB
Catchment Area

Embankment Crest Level

Full Supply Level

Square Kilometer

Land and Survey Datum

Million Cubic Meter

Mean Sea Level

National Hydraulic Research Institute of Malaysia

Probable Maximum Precipitation

Probable Maximum Flood

Spillway Design Flood

Sungai

Syed Mohammad Hooi Binnie 